\title{
Modernization's Doppelgänger
}

\section{Peter Mandler}

Gonville and Caius College, Cambridge

E-mail: pm297@cam.ac.uk

Daniel Immerwahr, Thinking Small: The United States and the Lure of Community

Development (Cambridge MA, 2015).

Jeremy Adelman, Worldly Philosopher: The Odyssey of Albert O. Hirschman (Princeton NJ, 2013).

Modernization theory has rightly become a central topic of twentieth-century U.S. intellectual history. ${ }^{1}$ Not only does it represent a key movement in modern economics, but modernization theory's purposeful interdisciplinarity ropes in psychology, sociology and political science (at least), and makes it stand as one of the main pillars of the new interdiscipline of behavioral science that was so influential in the postwar Western academy. As an equally purposeful policy science, modernization theory also played an important role in a raft of postwar political initiatives - in the Cold War, in international economic development, in the organization of science, in counterinsurgency and the Vietnam War. This unusually fruitful (albeit often unusually destructive) intermeshing of ideas and politics has been neatly exemplified in the person of Walt Rostow, "America's Rasputin", who parlayed a politically unpromising track record as an economic historian into a role as one of

\footnotetext{
1 Beginning with an extraordinary cluster of books published almost simultaneously: Nils Gilman, Mandarins of the Future: Modernization Theory in Cold War America (Baltimore, 2003); David C. Engerman, Modernization From the Other Shore: American Intellectuals and the Romance of Russian Development (Cambridge MA, 2003); David C. Engerman, Nils Gilman, Mark H. Haefele and Michael E. Latham (eds.), Staging Growth: Modernization, Development, and the Global Cold War (Amherst MA, 2003; and, leading the pack chronologically, Michael E. Latham, Modernization as Ideology: American Social Science and 'Nation Building' in the Kennedy Era (Chapel Hill NC, 2000).
} 
the principal strategists of the Vietnam War. ${ }^{2}$ Opinion differs as to how determinative modernization theory's ideas were; Bruce Kuklick has suggested of most social science in this period that it "served to legitimate but not to energize politics"; or, as a participant put it more trenchantly in 1949, "The administrator uses social science the way a drunk uses a lamppost, for support rather than for illumination." 3 Still, most intellectual historians would be happy (though not necessarily proud) to think that their key concepts provided even support for the major political enterprises of their day.

Modernization theory should probably be considered as only one, highly discrete phase in the broader history of developmentalism, that is, the idea that economic development is the highest (in some variants the only) goal of politics. Though clearly economic development as a goal of government can be traced back at least as far as mercantilism and cameralism, until the nineteenth century it had to compete with religion and liberty, and really only came into its pomp when religion began to fade as a central concern of government towards the end of the nineteenth century; it is no coincidence that many social scientists were the children of clergy and missionaries. Competing variants of developmentalism that have also received their due in recent intellectual historiography include ideas of trusteeship in late-imperial policy ${ }^{4}$, Communist developmentalism $^{5}$, and, especially, the rise of neoliberalism ${ }^{6}$, which can claim some of the same hegemony over

\footnotetext{
2 David Milne, America's Rasputin: Walt Rostow and the Vietnam War (New York, 2008).

3 Bruce Kuklick, Blind Oracles: Intellectuals and War from Kennan to Kissinger (Princeton, 2006), 15; Alexander H. Leighton, Human Relations in a Changing World: Observations on the Use of the Social Sciences (New York, 1949), 127-8.

4 A fine recent example is Helen Tilley, Africa as a Living Laboratory: Empire, Development, and the Problem of Scientific Knowledge, 1870-1950 (Chicago, 2011), esp. ch. 2.

5 Odd Arne Westad, The Global Cold War (Cambridge, 2005) is particularly original in combining modernization theory, Communist developmentalism, and 'Third World' responses.

${ }^{6}$ Predictably, a decade after the cluster of modernization-theory books, we have now seen a cluster of neoliberalism books, of similarly high quality: e.g. Angus Burgin, The Great Persuasion: Reinventing Free Markets since the Depression (Cambridge MA, 2012); Daniel Stedman Jones, Masters of the Universe: Hayek, Friedman, and the Birth of Neoliberal Politics (Princeton NJ, 2012); Philip Mirowski, Never Let a Serious Crisis Go to Waste: How Neoliberalism Survived the Financial Meltdown (London, 2013); and, for a broader interpretation of late $20^{\text {th }}$-century history which puts neoliberalism at the centre, Daniel T. Rodgers, Age of Fracture (Cambridge MA, 2011).
} 
public policy since the 1980s that modernization theory claimed for the 1950 s and 1960 s, and indeed shared some of the same intellectual roots in the interwar period.

What makes the modernization-theory variant of developmentalism so distinctive? Nils Gilman and Michael Latham have drawn out a number of connected strands: its optimism about the applicability of Western (particularly American) growth models to the whole world, including the least developed economies; its interdisciplinarity, locating the sources or nemeses of growth at the same time in institutional structures, personality types, social structures, and social values and attitudes; and its congruence with American Cold War liberalism, which gestated it in the 1950s, brought it briefly to power in the Kennedy and Johnson Administrations, and then declined with it in the 1970s. Gilman goes so far as to call it "a high-concept version of Americanism: materialism without class conflict, secularism without irreverence, democracy without disobedience". 7 Both Gilman and Latham also helpfully teased out sub-variants within the modernization-theory variant, differentiating not only among the psychological, economic, sociological and political approaches, but also between harder and softer approaches, depending on whether modernization was seen as a natural and inevitable, historically implied, or artificial, activist process. Gilman in particular majored on the "darker" variant associated with Gabriel Almond and Lucian Pye, who dwelt upon the obstacles to modernization and thus advocated a more interventionist policy in dealing with less-developed economies, what one early modernizer called "hitting the solar plexus" of a pre-modern society, "necessary to make large changes in an antiquated social structure by striking at its key points". ${ }^{8}$

Now, a decade later, at about the same time as neoliberalism has moved onto the intellectual-history stage, we are also experiencing a second-wave of modernization-theory

\footnotetext{
7 Gilman, Mandarins of the Future, 13-14.

8 Latham, Modernization as Ideology, 59-66; Gilman, Mandarins of the Future, 113-14; 'First Conference on Social Science Problems of Point Four', SSRC, Washington, 2 Dec. 1950, p. 3: Margaret Mead Papers, Library of Congress, E125.
} 
texts, in which the sub-variants themselves are tested and modernization theory's critics and bystanders are introduced. ${ }^{9}$ Daniel Immerwahr's Thinking Small deliberately inverts the primacy of modernization theory in the mid-twentieth century by rehabilitating a parallel tradition of "small-group" thinking and communitarian ideology. To uncover this tradition, Immerwahr argues, it is necessary first to identify and deconstruct the unilinear narrative of modernity that we have inherited from modernization theory itself and, before it, from the developmentalist granddaddies of modern social theory, Marx, Durkheim and Weber. ${ }^{10} \mathrm{He}$ calls this narrative "Modernization Comes to Town", the nearly ubiquitous story of "how a world that was once rooted in local, heterogeneous, informal, flexible, pluralistic, and, above all, small-scale institutions was lost". "Loss" is a keyword here, because thinking about community as a thing of the past allows one to have one's cake and eat it too - to enjoy the fruits of modernity and to wax elegiac about "the world we have lost". ${ }^{2}$ So "Modernization Comes to Town" is a story told by critics of modernization as well as, with Schadenfreude, its celebrants.

Immerwahr points instead to the persistence of the "local, heterogeneous, informal, flexible, pluralistic, and, above all, small-scale" idea of community even in the strongholds of modernization theory, that is, academia and development policy. Communitarianism's acein-the-hole was America's enduring love affair with small-town life, and even, at a stretch,

9 e.g., ahead of the curve, David C. Engerman, Know Your Enemy: The Rise and Fall of America's Soviet Experts (Oxford, 2009), on liberal Sovietologists' application of modernization theory to the understanding of Communist systems; Nick Cullather, The Hungry World: America's Cold War Battle Against Poverty in Asia (Cambridge MA, 2010), on a variety of modernization approaches to agricultural production; some of the contributors to Mark Solovey and Hamilton Cravens (eds.), Cold War Social Science: Knowledge Production, Liberal Democracy, and Human Nature (New York, 2012) and to Joel Isaac and Duncan Bell (eds.), Uncertain Empire: American History and the Idea of the Cold War (Oxford, 2012); and I would put my own book into this camp, Return from the Natives: How Margaret Mead Won the Second World War and Lost the Cold War (London, 2013).

${ }^{10}$ Immerwahr, Thinking Small, 13; and cf. 35, where he says something rather different, that it is 'the political ambidexterity' of communitarianism that has 'largely erased it from our historical memory', about which more below.

11 Ibid., 5 .

12 The reference here is to Peter Laslett, The World We Have Lost: England Before the Industrial Age (London, 1965), very much a product of modernization theory (and overseen by the modernization guru Edward Shils), though also critical of it and unremittingly anti-nostalgic. 
with the peasant, construed as the family farmer. Immerwahr argues that this love affair reached something of a peak in the 1930s, in the heyday of Norman Rockwell and Thornton Wilder and Frank Capra, and in the New Deal's obsession with rural development, which gave community development its first policy foothold in the Department of Agriculture's Bureau of Agricultural Economics. One beneficiary of this romance, and in some ways the hero of Immerwahr's book, was the anthropologist Robert Redfield, who worked for a time as a consultant for the Bureau of Agricultural Economics, and whose fieldwork among peasants in Mexico (published as Tepoztlan, 1931, and Chan Kom, 1934) showed Americans - and development officials - how the romance of the small farmer could be seen also playing itself out in the most unlikely places in the developing world. Redfield, who as Immerwahr observes is sometimes seen as one of the first modernization theorists, was in truth a keen-eyed observer of modernization processes but an advocate for peasant communities able to preserve their "little traditions" within those processes - a not uncommon blend of roles amongst anthropologists of the day. ${ }^{13}$

A similarly subtle embedding of community consciousness within modernization processes is evident when Immerwahr turns to the place of community development within Cold War development programs. Needless to say, India had an even stronger romance with the small farmer than New Deal America, and Immerwahr argues that this indigenous romance was put to good use by American development planners in India such as Ellery Foster (another veteran of the Bureau of Agricultural Economics) and Albert Mayer (who cut his teeth on planning "Green Belt" towns in the New Deal). In this account, Nehru appears not as the betrayer, the apostle of Western-style modernization, as he has often been portrayed, but rather as the true heir of Gandhi. It is only with Nehru's death in 1964, and the succession of his daughter, Indira Gandhi, in 1966, that the pendulum swings back to

13 Immerwahr, Thinking Small, 57-9. 
modernization pur sang (uncoincidentally at modernization theory's highpoint of influence in Washington), given a savage twist by Gandhi's personal authoritarianism.

A less benign embedding of community consciousness within modernization processes is displayed in the unlikely figure of Colonel Edward Lansdale, perhaps the model for Eugene Burdick and William Lederer's Ugly American (1958), outed as the architect of American counterinsurgency strategy in the Philippines and Vietnam by Neil Sheehan in his classic A Bright Shining Lie: John Paul Vann and America in Vietnam (1988), and subsequently a linchpin in many books on the connections between modernization theory, counterinsurgency and American foreign policy. To Immerwahr, however, Lansdale's promotion of a community-development strategy in the Philippines looks more like Mayer's program in India. ${ }^{14}$ It is at this point that doubts may arise about the excessive elasticity of Immerwahr's concept of the small group or community, which can serve as readily as modernization theory's most effective tool as its nemesis.

There are, after all, small groups and small groups. There are the small groups that are distinctive cultures, true communities, and which advocates like Redfield sought to defend against the monoculture of modernization. And there are the small groups that modernization theorists assemble in laboratories to test theories about allegedly universal human traits. These could be randomly selected or artificially constituted groups, such as the squads of GIs dissected by the famous sociological study of The American Soldier (1949), which derived a range of ideas crucial to postwar behavioral science and thus to modernization theory, such as the "primary group", the "frame of reference", and the concept of "relative deprivation". ${ }^{15}$ Immerwahr scoops such studies into his ambit, as if they were all in some way defending existing communities in the way that Redfield was, rather than

14 Ibid., 112-13.

15 See, e.g., Peter Buck, 'Adjusting to Military Life: The Social Sciences Go to War, 1941-1950', in Merritt Roe Smith (ed.), Military Enterprise and Technological Change: Perspectives on the American Experience (Cambridge MA, 1985), 203-52, and Robin M. Williams, Jr., 'The American Soldier: An Assessment, Several Wars Later', Public Opinion Quarterly 53 (1989), 155-74, among many studies. 
studying existing communities (or constituting artificial ones), the better to derive universal principles of human action in groups for modernizing purposes. ${ }^{16}$ It's not that Immerwahr is unaware of the differences; but as he slips from one to the other, it is sometimes difficult to gauge what politics (or indeed what ideas of nature and culture) are in play at any particular time. And in pursuing the idea of "community development without modernization" he tends to downplay the equally powerful idea of "community development for modernization". ${ }^{17}$ When, for example, he recounts an apparently comic encounter between his community developers and the barons of modernization theory at a MIT conference in 1957, he concludes that the latter simply couldn't understand the former. To the contrary, I would argue, they had a very precise understanding of the value of community development; and indeed, Immerwahr quotes Lucian Pye's view at this meeting that community development was a technique for creating "a modern nation - in which secular and industrialized modes of behavior will be secure and dominant - out of an earthbound society, predominantly composed of a population that is fragmented into tightly ordered village units". ${ }^{18}$

Immerwahr might have spelled out these tensions more clearly from the beginning, and tracked more explicitly the points at which "community development" declares itself modernization's nemesis, or at which it becomes modernization's most potent tool, and, most interestingly, the points in between where strange bedfellows acted together simultaneously on both premises. But to have done so would also have spoiled some of the apparent ironies upon which Immerwahr relies for narrative drive. Modernization theorists captured both the Indian and the Philippine community-development programs, not so much by twist of fate or sleight of hand, as it appears in Immerwahr's suspenseful narrative, but because they had always also been interested in small-group dynamics, for very different reasons. Depending

${ }^{16}$ Cf., for example, Immerwahr, Thinking Small, 30-4, with the discussion of The American Soldier in Ron Robin, The Making of the Cold War Enemy: Culture and Politics in the Military-Intellectual Complex (Princeton, 2001), 19-25.

17 Immerwahr, Thinking Small, 61.

${ }^{18}$ Ibid., 62. 
on your outlook, the Indian village could be seen as a laboratory for grassroots participation by the poor, or as an instrument of central economic policy in which local landlords and officials played all the key roles. Even more clearly, in the Philippines, Lansdale and his allies always saw the village as an instrument for a policy determined elsewhere - an antiCommunist as well as a modernization policy. In a social-engineering vein very reminiscent of The American Soldier, the principal community-development agency in the Philippines adopted a "therapeutic approach to rural problems" aimed at harnessing grassroots labour to elite projects. ${ }^{19}$ No wonder that Walt Rostow praised programs like Lansdale's as "a mixture of attractive political and economic programs in the underdeveloped areas and a ruthless projection to the peasantry that the central government intends to be the wave of the future". ${ }^{20}$ Even Redfield, as we have seen, could be mistaken for a modernization theorist himself - not without some shreds of reason. ${ }^{21}$ As Immerwahr acknowledges, Redfield himself fudged the distinction by gravitating towards those peasant communities like Chan Kom whose cultures were happily congruent with modern values: "These villagers had much of the Protestant ethic before they had ever heard of Protestantism."22

In Immerwahr's handling, this central ambiguity in the mission of community development comes back to bite policymakers when it is brought home in the 1960s, in the form of War on Poverty programs such as VISTA and especially the programs launched from Sargent Shriver's Office of Economic Opportunity (OEO). These programs were not on the whole designed by the community-development specialists, though Immerwahr shows connections to them through the important agency of Oscar Lewis, yet another veteran of the

19 Ibid., 116-17.

20 Quoted by Milne, America's Rasputin, 87-8.

${ }^{21}$ Clifford Wilcox, Robert Redfield and the Development of American Anthropology (Lanham MD, 2004), 2-3, 43-60, 77, 92-9, 122-9, distinguishes between his more 'positivist' and 'moralist' phases.

${ }^{22}$ Immerwahr, Thinking Small, 58-9. This fudge was also adopted by Margaret Mead, who deliberately chose to focus on the Manus people of the South Pacific for precisely the same reason, though she was no more a fan of a global monoculture than Redfield: Mandler, Return from the Natives, 257, 278-80. It is not the same stance as that adopted by Manning Nash, for example, in Machine Age Maya: The Industrialization of a Guatemalan Community (Chicago, 1958), which was confessedly pro-modernization and argued almost for the intrinsic compability of modernization and community integrity. 
Bureau of Agricultural Economics and a student of Redfield's Tepoztlan, who invented the idea of the "culture of poverty". These programs were, after all, mainly a product of the Kennedy and Johnson Administrations and of Cold-War liberals like Daniel Patrick Moynihan, who were however shocked by their outcomes. Strategies that had appeared "safe" to modernizing liberals in India and the Philippines, where they could rely on local landlords and authoritarian states, turned explosive when they fell into the hands of ' $60 \mathrm{~s}$ radicals - the "maximum feasible misunderstanding", as Moynihan pungently put it, riffing on the fatal goal of "maximum feasible participation" which he blamed on the communitydevelopment specialists. Johnson's solution was to pretend American cities were like Indian or Philippine ones, and to incorporate local officials ("a new class of Brahmins", as Immerwahr nicely puts it); his 1967 bill to reorganize the OEO would have put mayors on the board of every federally-funded community action agency, and Congress added yet another layer of state and local government supervision. The goal was, precisely as Gilman describes the modernization vision, "participation without insubordination". ${ }^{23}$ Its failure, so close to home, spelled the end of both community development and modernization theory another indication that these two movements were Doppelgänger as much as they were antagonists.

In concluding with some reflections on the revival of communitarianism since the 1990s, Immerwahr regrets the "fog of amnesia surrounding the history of community development": development workers move about too much to develop long memories, they are often too overwhelmed by immediate practicalities to pause for historical reflection, and in any case the history has been dominated by modernization theory. ${ }^{24}$ Obviously he hopes that his own historical reflections may help to overcome this amnesia; and if any historiography is likely to tell with policymakers, it ought to be this kind of book, short,

23 Immerwahr, Thinking Small, 161.

24 Ibid., 177. 
stylish, lucid and passionate. But amnesia seems to me (and also, I think, to Immerwahr) generally too easy an opening for historians, too obvious a demand for our services. In this case, community development was overwhelmed by the political and economic power of modernization, which annexed community development to itself rather than acknowledging it as critique or opposition.

It's not as if community-developers, and other, more potent voices, weren't warning all along about the flaws in top-down modernization. Immerwahr says that community development wasn't "noisy" enough, but it may have been, rather, that the men in power weren't listening, or didn't need to listen. Probably the most famous development theorist outside the modernization camp, Albert Hirschman, was voicing community-development concerns all along, pari passu with the ascendancy of modernization theory, at least from 1952 when this young émigré economist turned away from early work on the reconstruction of the European economy to the concerns of the developing world, on a World Bank mission to Colombia. It is curious that Immerwahr does not mention Hirschman once - a casualty of his book's tightness and economy - as his outlook, though rooted in European social democracy and anti-fascism rather than the New Deal and the Bureau of Agricultural Economics, and in economics rather than anthropology, was strikingly similar. Hirschman was not an out-and-out opponent of modernization theory, and to some extent his interest in community development was motivated by a desire to make modernization projects work. But his intellectual bent was wholly against the kind of central planning that modernization as much as Marxism embraced - the idea that economies, cultures, societies were so articulated that they even had a solar plexus, much less one that could be satisfactorily struck. His skeptical rationalism, forged in the crucible of catastrophic authoritarianism he had witnessed on his journey out of Nazi Germany and in his wartime analyses of the European economy under fascism, predisposed him to petites idées, to "intermediate links", to pluralistic 
strategies, and to the ironies and unintended consequences of ideas that were too big and too clumsy for complex human societies.

It also predisposed him to the close, empirical study of communities from the grassroots, where "observation from the ground up", as Jeremy Adelman puts it in his sprawling biography of Hirschman, trumped "over-all, integrated development programs". 25 Against the modernization thesis of "balanced growth" - growth achieved by means of a "big push" across all sectors - he counterposed a vision of "unbalanced growth", that embraced sectoral, regional and local diversity, and anticipated creative outcomes from the resulting contradictions. His method of study was based not on aggregated statistics and macroeconomic models but on incessant travel: from this irrigation project in Peru to that paper mill in Pakistan to this branch railway line in Nigeria. His books and reports were dominated not by soaring architecture but by case studies. And he was more attached politically to the kind of democracy that distributed power - even at the cost of, or perhaps with the bonus of, uncoordinated growth - than to the authoritarian nationalists in the developing world whom the modernization theorists found essential to coordinating the "big push".

Hirschman did not (so far as one can tell from Adelman's account) speak the language of "community" or have much to do directly with the community development movement described by Immerwahr - neither its overseas nor its domestic wing. ${ }^{26}$ But he was much better placed than the community developers to make their critique of modernization theory from within, because he was never identified as an outright oppositionist, was much employed by some of the principal agencies of modernization (the World Bank, RAND, the Ford Foundation), begged by them to evaluate their programs, and went out of his way to position himself in the mainstream - he abjured his preferred term "unbalanced growth" so as

\footnotetext{
25 Adelman, Worldly Philosopher, 323.

${ }^{26}$ He was, however, aligned in Latin America with the cause of land reform, which Cullather places alongside community development as viable agrarian strategies before the late 1950s when modernization priorities ('yields, resources, and revenues') won out: Cullather, Hungry World, 106.
} 
not to be dismissed as only perverse. Even so, his critiques often went unheard - a matter not of amnesia but of deafness, his audience not wanting or needing to hear. Some of this deafness was structural: Hirschman's critique of central planning offered no practical solutions for central planners except delegation of their powers to locals; for this reason, he was most effective when addressing Latin American authorities who were undergoing (sadly short-lived) exercises in decentralization, Colombia and Brazil in the early 1960s, Chile later in the decade. But part of the deafness was willful. Adelman describes the response of the World Bank to Hirschman's major evaluation of their development work, Development Projects Observed (1967), as "ungenerous and churlish". It was more than that - as Adelman says on the next page, the World Bank was "unaccustomed to letting outsiders be anything more than beneficiaries or, when things went wrong, blameworthy". ${ }^{27}$ They weren't under any pressure to act otherwise. They knew Hirschman had lessons to teach them - an internal account written a few years later granted that although Hirschman's report “does not lend itself to use as a manual for the instruction of the would-be project appraisers. . the insights it provides could be neglected by such appraisers only at considerable cost" - but such acknowledgements, Adelman says, came "too little, too late". ${ }^{28}$

Hirschman's full life endowed him early on with an air of world-weariness, but even the most hopeful and energetic - and Hirschman was one of those - would have to be worn down by the persistence and scale of such sublime disregard. No wonder he retreated increasingly into academia - ultimately into its most eremitical redoubt, the Institute for Advanced Study at Princeton - and is now probably better known as a social theorist (the author of Exit, Voice, and Loyalty and The Passions and the Interests) than as a development expert. This narrative arc gives Adelman's book a mournful, frustrated cast - one of the closing chapters is entitled "Disappointment" - although it would be impossible not to enjoy

27 Ibid., 398-9.

${ }^{28}$ Ibid., 406-7. 
such a dazzlingly interesting life nor (at least for me) to admire such a humane and fertile thinker. ${ }^{29}$ But the message for Immerwahr and for the fortunes of community development is clear. As Immerwahr himself grants, "[m] odernizers had gravity on their side". ${ }^{30}$ This is a pretty powerful concession. It does not mean that we must take the modernization story for granted or at face value, but it does mean that we need to appreciate better the power that lay behind it. Especially if, as Immerwahr hopes, the recovery of the community-development counter-narrative is to do some political work in the present, it's not enough to tell its story. Gauging its inherent weaknesses and its adversaries' strengths is just as important, and to do that probably requires more structural analyses equivalent to, if more sophisticated, than the Weberian framework that Immerwahr deems inadequate, and which he fleetingly seeks to supplement in his closing pages. But at least, as Immerwahr very clearsightedly says on his last page, telling the communitarian story "is to give up on a fantasy, the fantasy that community is the great untried experiment of the industrial age". ${ }^{31}$

\section{Peter Mandler}

Gonville and Caius College, Cambridge

\footnotetext{
29 These qualities merit the high praise lavished upon the book by reviewers, but I cannot agree with those who describe the book as well-written, littered as it is with malapropisms, typoes and abuse of English: poring confused with pouring, people's with peoples' (repeatedly: apostrophes a weakness throughout), clairvoyance with clarity, internship with internment, wallowing with (I imagine) languishing, absconding with stealing, diminished with minimized, grizzly with grisly, reign with rein, borne with born, intension with intention, detraction with distraction, foregone with foreordained, defrocking with debunking; inventions such as 'cheek to jowl', 'curriculum vita' (and 'vitae' as a singular), 'setting his heights' (for 'sights'), 'loggerhead', 'straightlaced', 'University of Indiana' and 'Frances Fukuyama'; correspondences as the plural of correspondence and minuscule spelled as miniscule (to mention only some errors and none of the many infelicities).

${ }^{30}$ Immerwahr, Thinking Small, 5.

31 Ibid., 184.
} 